\title{
Anti-inflammatory Role of Mesenchymal Stem Cells in an Acute Lung Injury Mouse Model
}

\author{
Jin Won Huh', Won Young Kim², Yun Young Park ${ }^{3}$, Chae-Man Lim¹, Younsuck Koh ${ }^{1}$, Mi-Jung Kim³, \\ Sang-Bum Hong ${ }^{1}$
}

${ }^{1}$ Department of Pulmonary and Critical Care Medicine, Asan Medical Center, University of Ulsan College of Medicine, Seoul; ${ }^{2}$ Department of Emergency Medicine, Asan Medical Center, University of Ulsan College of Medicine, Seoul; ${ }^{3}$ Asan Institute for Life Sciences, Seoul, Korea

Background: Mesenchymal stem cells (MSCs) attenuate injury in various lung injury models through paracrine effects. We hypothesized that intratracheal transplantation of allogenic MSCs could attenuate lipopolysaccharide (LPS)-induced acute lung injury (ALI) in mice, mediated by anti-inflammatory responses.

Methods: Six-week-old male mice were randomized to either the control or the ALI group. ALI was induced by intratracheal LPS instillation. Four hours after LPS instillation, MSCs or phosphate-buffered saline was randomly intratracheally administered. Neutrophil count and protein concentration in bronchoalveolar lavage fluid (BALF); lung histology; levels of interleukin (IL)-1 $\beta$, IL-6, tumor necrosis factor (TNF)- $\alpha$, and macrophage inflammatory protein-2; and the expression of proliferation cell nuclear antigen (PCNA), caspase-3, and caspase-9 were evaluated at 48 hours after injury.

Results: Treatment with MSCs attenuated lung injury in ALI mice by decreasing protein level and neutrophil recruitment into the BALF and improving the histologic change. MSCs also decreased the protein levels of proinflammatory cytokines including IL- $1 \beta$, IL-6, and TNF- $\alpha$, but had little effect on the protein expression of PCNA, caspase-3, and caspase-9.

Conclusions: Intratracheal injection of bone marrow-derived allogenic MSCs attenuates LPSinduced ALI via immunomodulatory effects.

Key Words: acute lung injury; cytokines; immunomodulation; inflammation; lipopolysaccharides

\section{INTRODUCTION}

Though the management of acute lung injury (ALI) and acute respiratory distress syndrome (ARDS) has progressed, the mortality rate remains very high at $30 \%-50 \%$ [1-3]. Clinical research has shown that low tidal volume ventilation, the prone position, and extracorporeal membrane oxygenation significantly decrease the mortality rate [4-6]. Although ALI has various causes such as sepsis, pneumonia, pancreatitis, trauma, and burns $[7,8]$, it is known that the common mechanism is the severe inflammatory injury to the endothelium and epithelium resulting in a compromised pulmonary barrier, which leads to permeability edema. A treatment goal can be the effective blockage of this common mechanism [9]. Inflammatory mediators such as cytokines, reactive oxygen species, leukotrienes, and products of complement activation increase in the bronchoalveolar lavage fluid (BALF) of a patient with ALI.

\section{Original Article}

Received: December 23, 2017

Revised: April 6, 2018

Accepted: July 4, 2018

Corresponding author

Sang-Bum Hong

Department of Pulmonary and

Critical Care Medicine, Asan Medical

Center, University of Ulsan College

of Medicine, 88 Olympic-ro 43-gil,

Songpa-gu, Seoul 05505, Korea

Tel: +82-2-3010-3893

Fax: +82-2-3010-6968

E-mail: sbhong@amc.seoul.kr

Copyright (@) 2018 The Korean Society of Critical Care Medicine

This is an Open Access article distributed under the terms of Creative Attributions Non-Commercial License (http:// creativecommons.org/li-censes/by-nc/4.0/ which permits unrestricted noncommercial use, distribution, and reproduction in any medium, provided the original work is properly cited. 
From a morphological point of view, the early stage of ALI shows an infiltration of neutrophils into the lung tissue. This transfer of neutrophils into the lung tissues is caused by neutrophil migrating factors such as neutrophil chemotactic factor and cytokines $[10,11]$. Moreover, one study reported that when lipopolysaccharide (LPS) or tumor necrosis factor (TNF) is injected into a neutrophil-deficient animal, the lung damage decreases $[11,12]$ and is dependent on the functional changes of the neutrophil. These results suggest that preventing or reducing the infiltration of neutrophil can reduce ALI [13].

Mesenchymal stem cells (MSCs) have multilineage differential flexibility that allows for differentiation in tissue damage [14]. Recent studies have suggested that bone marrow-derived multipotent MSCs may have therapeutic applications in several clinical disorders, including hepatic failure, sepsis, and myocardial infarction [15-19]. Because MSCs can differentiate into type I and II epithelial cells, vascular endothelial cells, and fibroblasts during lung injury [20,21], they have been studied in vivo in several animal models of lung diseases. However, the engraftment of MSCs into damaged tissue is rare. Recent studies have reported the therapeutic effect of MSCs through a paracrine mechanism by the modulation of cytokine or growth factor $[16,18,22]$. This study was performed to evaluate the anti-inflammatory effect of MSCs in an LPS-induced ALI model.

\section{MATERIALS AND METHODS}

\section{Animals and Experimental Drugs}

Six-week-old male C57BL/6 mice weighing 21-22 g (Daehan Bio Link, Eumseong, Korea) were divided into the four groups as follows: (1) the control group (CTL, $n=12$ ), (2) the LPS only group (LPS, $n=12$ ), (3) the MSCs only group (MSC, $n=6$ ), and (4) the MSCs administration following LPS-induced ALI group (LPS/MSC, n=9). LPS (Escherichia coli Serotype 055:B5; Sigma-Aldrich, St. Louis, MO, USA) powder was dissolved in a saline solution and $5 \mathrm{mg} / \mathrm{kg}$ was injected intratracheally to induce ALI [23]. Four hours after the injection of LPS, the mice were anesthetized and MSCs $\left(7.5 \times 10^{5}\right.$ cells in $30 \mu \mathrm{l}$ of PBS) were injected into the trachea. Mice were killed 48 hours after the LPS injection [24]. We collected BALF for cell analysis and cytokine measurement and lung tissue for histology. To anesthetize the mice, ketamine at $70 \mathrm{mg} / \mathrm{kg}$ (Yuhan Pharma, Seoul, Korea) and xylazine hydrochloride at $9 \mathrm{mg} / \mathrm{kg}$ (Bayer Korea, Seoul, Korea) were used. All animals were cared for according to the guidelines of the Institutional Animal Care and Use Committee of Asan Medical Center (No. 2009-13-115).

\section{KEY MESSAGES}

- Treatment with mesenchymal stem cells (MSCs) attenuated acute lung injury (ALI) by decreasing neutrophil recruitment into the bronchoalveolar lavage fluid and the protein levels of proinflammatory cytokines including interleukin (IL)-1 $\beta$, IL-6, and tumor necrosis factor- $\alpha$.

- The therapeutic effect of MSCs in the lipopolysaccharide-induced ALI model may be associated with an anti-inflammatory effect via immunomodulation.

\section{Isolation and Administration of MSCs}

Bone marrow-derived cells were isolated from the femur of 4-week old male C57BL/6 mice. Plastic-adherent MSCs were cultured as previously described, but with a slight modification. Bone marrow-derived cells were plated in plastic culture dishes (SPL Life Sciences, Pocheon, Korea) with complete media (Dulbecco's Modified Eagle's Medium containing 10\% fetal bovine serum, penicillin, $100 \mathrm{mM}$ sodium pyruvate, and streptomycin) and incubated at $37^{\circ} \mathrm{C}$ in a humidified atmosphere with $5 \% \mathrm{CO}_{2}$. Two days later, unattached cells were removed by washing with complete media, which was replaced and changed once or twice per week. Fourth-passage MSCs were administered to the mice. Monoclonal antibodies, including CD34, CD45, CD73, and CD90 that were fluoresceinlabelled with fluorescein isothiocyanate or phycoerythrin, were used to confirm the purity of the MSCs [25]. CD34 and CD45 did not appear if it was positive for CD73 and CD90 (Supplementary Figure 1). Therefore, this study confirmed that the cultured cells maintain the characteristics of MSCs.

\section{Measurement of Neutrophil Count and Protein Content in BALF}

The protein content in the BALF was measured as per the Bradford's method. After a Diff-Quick stain, the number of neutrophils was measured using the method described by Everhart et al. [26]. Using a 400-times magnification optical microscope, 500 cells were counted to determine the proportion of neutrophils in the white blood cell population and calculate the number of neutrophils.

\section{Measurement of Cytokines in BALF}

TNF- $\alpha$, interleukin (IL)-1 $\beta$, IL-6, and macrophage inflammatory protein (MIP) were measured using an enzyme-linked immunosorbent assay (ELISA) kit (R\&D Systems, Minneapolis, MN, USA). 


\section{Myeloperoxidase Activity Assay}

Myeloperoxidase (MPO) activity in the serum was measured using a MPO kit (R\&D Systems).

\section{Western Blot Analysis}

The lung tissue was homogenized in a lysis buffer (20 mM Tris$\mathrm{HCl}, \mathrm{pH} 7.5,150 \mathrm{mM} \mathrm{NaCl}, 1 \mathrm{mM}$ ethylenediaminetetraacetic acid, $1 \mathrm{mM}$ ethylene glycol tetraacetic acid, $1 \%$ Triton X-100, $0.1 \%$ sodium dodecyl sulfate [SDS], $1 \% \mathrm{NP}-40,2.5 \mathrm{mM}$ sodium pyrophosphate, $1 \mathrm{mM}$-glycerophosphate, $1 \mathrm{mM} \mathrm{Na}_{3} \mathrm{VO}_{4}, 2$ $\mathrm{mM}$ p-nitrophenyl phosphate, and a protease inhibitor cocktail) on ice with a polytron tissue homogenizer (Brinkmann, Riverview, FL, USA). After centrifugation at 1,200 rpm for 10 minutes at $4{ }^{\circ} \mathrm{C}$, the proteins were separated in an $8 \%$ or $12 \%$ SDS-PAGE gel and transferred to a nitrocellulose membrane. The membranes were blocked with $5 \%$ skim milk for 1 hour at room temperature and then incubated with the primary antibody $(1: 500$ or $1: 1,000)$ overnight at $4^{\circ} \mathrm{C}$. After washing with
0.5\% Tween-20 in Tris-buffered saline (50 mM Tris, $150 \mathrm{mM}$ $\mathrm{NaCl}, \mathrm{pH}$ 8.0), the membranes were incubated with horseradish peroxidase-conjugated secondary antibody $(1: 5,000)$. Primary antibodies against the following proteins were used: caspase-3, caspase-9 (Cell Signaling Technology, Beverly, MA, USA), $\beta$-actin (Santa Cruz Biotechnology, Santa Cruz, CA, USA), and proliferation cell nuclear antigen (PCNA; Abcam, Cambridge, MA, USA).

\section{Histology Analysis}

The severity of lung injury was determined using paraffin embedded-lung sections stained with hematoxylin \& eosin. Ten sections per mouse were randomly chosen for the analysis. Lung injury was scored according to the following four categories: alveolar congestion, hemorrhage, neutrophil infiltration into the airspace or interstitum, and neutrophil infiltration into vessel. Each category was graded on a four point scale $(0-3)[27]$.
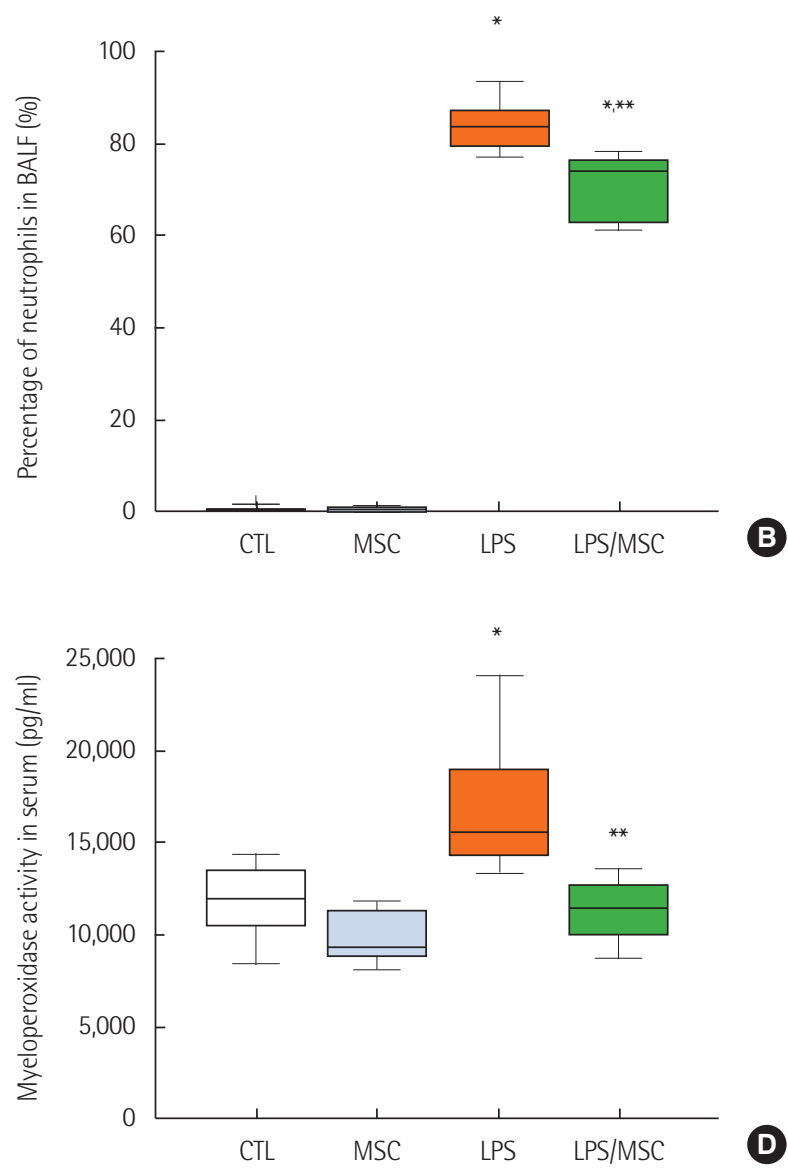

Figure 1. Mesenchymal stem cells attenuate lung injury in lipopolysaccharide-induced acute lung injury. (A) Total cell counts of bronchoalveolar lavage fluid (BALF). (B) Percentage of neutrophils in BALF. (C) Total protein level in BALF. (D) Myeloperoxidase activity in serum. CTL: control group; MSC: mesenchymal stem cell injected group; LPS: lipopolysaccharide-induced acute lung injury group; LPS/MSC: MSC injection following LPS induced acute lung injury group. ${ }^{*} \mathrm{P}<0.05$ compared to the CTL group; ${ }^{* *} \mathrm{P}<0.05$ compared to the LPS group. 


\section{Growth Factor Measurement}

The level of hepatocyte growth factor (HGF; EIAab, Wuhan, China) in BALF was measured via ELISA.

\section{Statistical Analysis}

All results are represented as mean and standard error of the mean. Mean values of different groups were analyzed using an independent-samples t-test. Successive data that do not follow normal distribution were analyzed using a Mann-Whitney U-test. Categorical data were analyzed using a chi-square test. All calculations were carried out using SPSS version 12.0 (SPSS Inc., Chicago, IL, USA) with a significance level set at $\mathrm{P}<0.05$.

\section{RESULTS}

\section{Attenuation of LPS-induced ALI by MSCs}

We investigated the total white blood cell count and neutrophil percentage of the BALF. The LPS group showed a significantly higher white blood cell count than the control group did (91.6 \pm $9.7 \times 10^{4} / \mathrm{ml}$ vs. $\left.36.2 \pm 2.9 \times 10^{4} / \mathrm{ml}, \mathrm{P}<0.05\right)$ and was significantly decreased in the LPS/MSC group $\left(58.9 \pm 4.4 \times 10^{4} / \mathrm{ml}, \mathrm{P}<0.05\right)$
(Figure 1A). The percentage of neutrophils was significantly higher in the LPS group when compared to that of the control group $(84.1 \% \pm 1.7 \%$ vs. $1.7 \% \pm 1.0 \%, \mathrm{P}<0.05)$ and lower in the LPS/MSC group when compared that of the LPS group ( $70.4 \% \pm$ $2.3 \%, \mathrm{P}<0.05$ ) (Figure 1B). Protein concentration in the BALF significantly increased in the LPS group when compared to that of the control group $(0.69 \pm 0.09 \mathrm{mg} / \mathrm{ml}$ vs. $0.20 \pm 0.02 \mathrm{mg} / \mathrm{ml}$; $\mathrm{P}<0.05)$. However, the LPS/MSC group did not have a significant decrease in protein concentration when compared to that of the LPS group $(0.49 \pm 0.05 \mathrm{mg} / \mathrm{ml} ; \mathrm{P}>0.05)$ (Figure 1C). LPS/MSC group significantly attenuated MPO activity (an indication of neutrophil accumulation) in serum when compared to that of the LPS group $(11,354 \pm 551.9 \mathrm{pg} / \mathrm{ml}$ vs. $17,139 \pm 973.6$ $\mathrm{pg} / \mathrm{ml}, \mathrm{P}<0.05$ ) (Figure 1D).

On histological analysis, the CTL (Figure 2A and B) and MSC (Figure 2C and D) groups also had normal parenchymal architecture without any exudates or edema. The LPS group showed an infiltration of inflammatory cells, mainly polymorphonuclear cells, into the alveolar space and interstitium. In addition, there was hemorrhage in the alveolar space (Figure 2E and F). However, the LPS/MSC group had a relatively wellmaintained alveolar space compared to that of the LPS group.

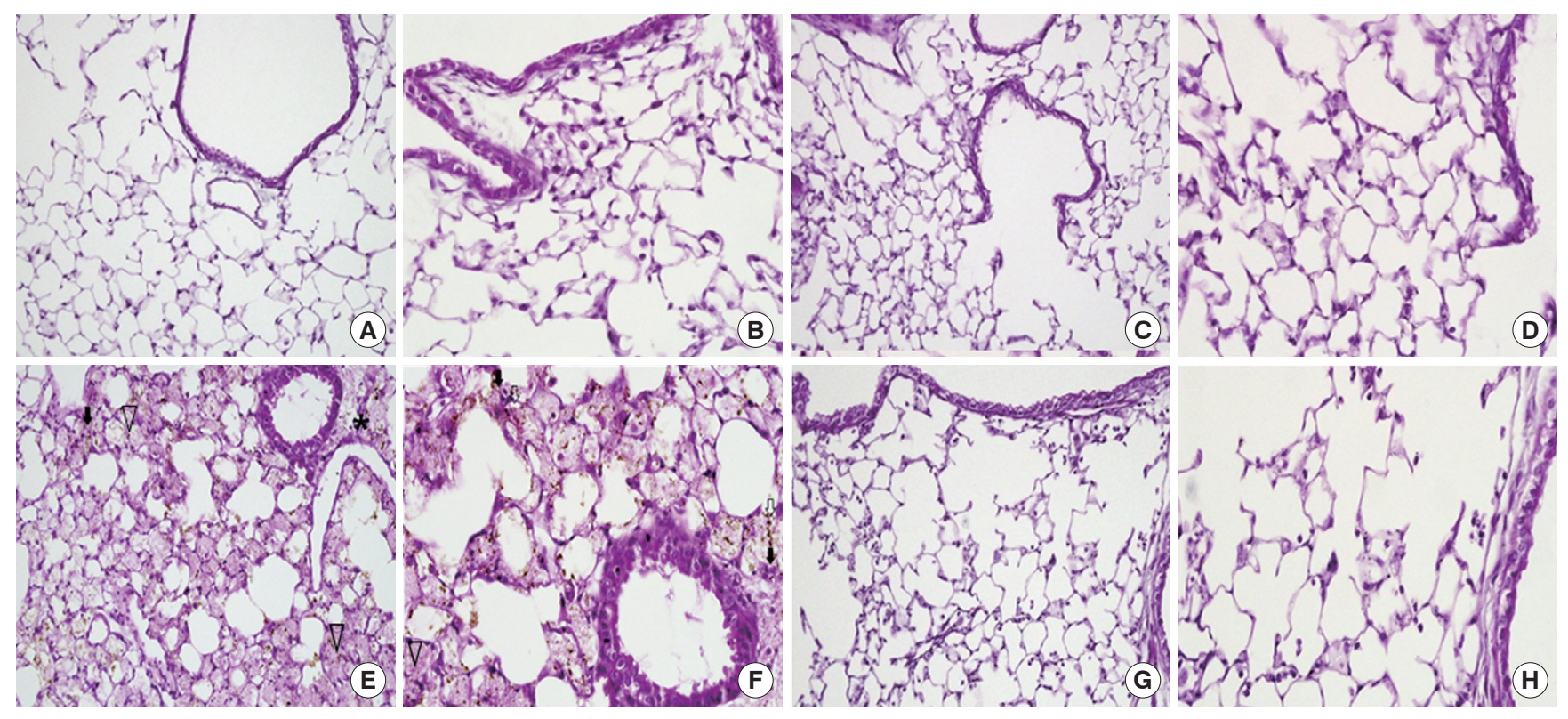

Figure 2. Light microscopy findings of the lung. $(\mathrm{A}, \mathrm{B})$ In the control (CTL) group, the normal parenchymal architecture, including the alveolar septa, alveolar lumen, and capillaries were well preserved. The infiltration of inflammatory cells was not observed. (C, D) In the mesenchymal stem cell (MSC) injected group, the normal pulmonary architecture was well preserved similar to that in the CTL group. (E, F) In the lipopolysaccharide (LPS)-induced acute lung injury group, the pulmonary architecture, including the alveolar septa and alveolar lumen were not preserved. Perivascular edema (asterisk) and intrapulmonary hemorrhage (arrow heads) were observed. The infiltration of inflammatory cells, perivascular cuffing (black arrows), and floating of phagocytes in the alveolar lumen (white arrows) were observed. (G, $\mathrm{H}$ ) In the MSC injection following LPS induced acute lung injury (LPS/MSC) group, the alveolar septa and alveolar lumen were relatively well preserved. Intrapulmonary hemorrhage and perivascular cuffing was less prominent compared to those of the lungs in the LPS group. The infiltration of inflammatory cells was not observed. (H\&E; magnification, $A, C, E, G: \times 200 ; B, D, F, H: \times 400$ ). 
Infiltration of inflammatory cells into the alveolar space and edema around the blood vessels decreased while there was almost no hemorrhage or edema in the alveolar space (Figure

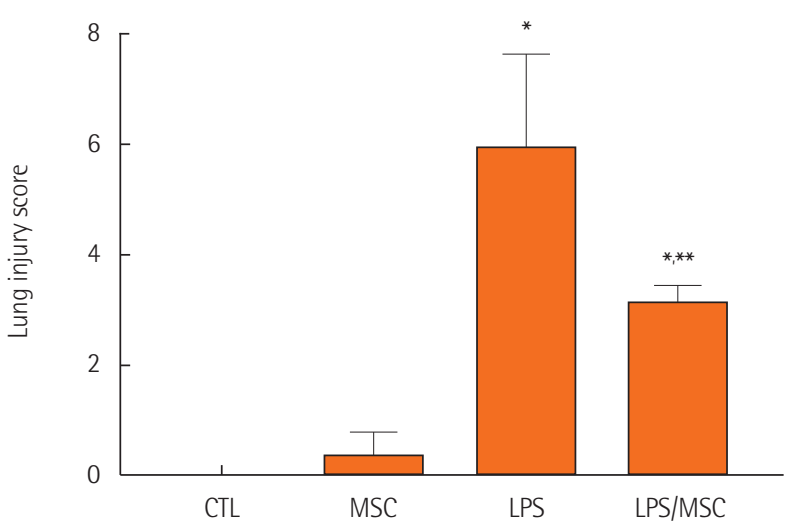

Figure 3. Lung injury scores. CTL: control group; MSC: mesenchymal stem cell injected group; LPS: lipopolysaccharide-induced acute lung injury group; LPS/MSC: MSC injection following LPS induced acute lung injury group. ${ }^{*} \mathrm{P}<0.05$, compared to the CTL group; ${ }^{* *} \mathrm{P}<0.05$, compared to the LPS group.
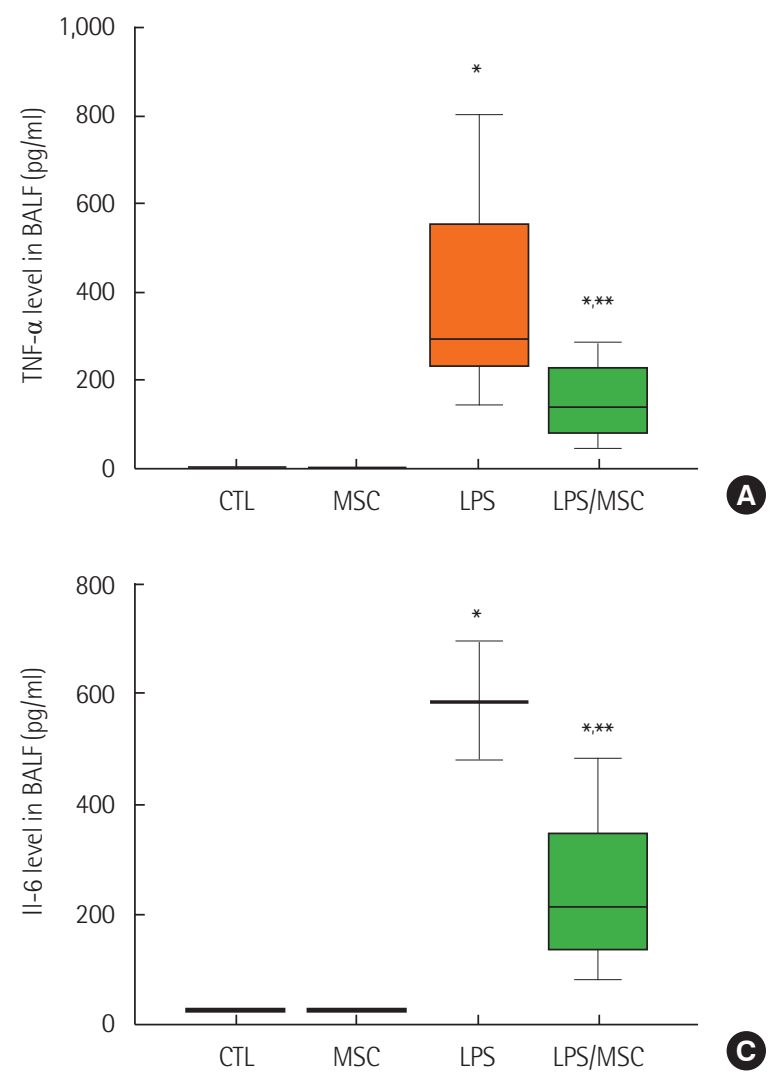

$2 \mathrm{G}$ and $\mathrm{H}$ ). To quantify the differences, lung injury was scored (Figure 3). LPS groups showed significant increases in lung injury score scores $(\mathrm{P}<0.05$, vs. CTL groups). LPS/MSC groups significantly attenuated the LPS-induced increases in injury scores $(\mathrm{P}<0.05$, vs. LPS groups).

\section{Anti-inflammatory Effect of MSCs in LPS-induced ALI}

The level of TNF- $\alpha$ was significantly higher in the LPS group when compared to that of the control group $(388.9 \pm 62.4 \mathrm{pg} / \mathrm{ml}$ vs. $0.1 \pm 0.1 \mathrm{pg} / \mathrm{ml}, \mathrm{P}<0.05)$. However, the level of TNF- $\alpha$ in the LPS/MSCs group (184.2 $\pm 41.8 \mathrm{pg} / \mathrm{ml})$ was significantly lower $(\mathrm{P}<0.05)$ when compared to the LPS group (Figure $4 \mathrm{~A})$. When compared to the control group, the LPS group had higher IL$1 \beta(0.0 \pm 0.0 \mathrm{pg} / \mathrm{ml}$ vs. $158.9 \pm 6.9 \mathrm{pg} / \mathrm{ml} ; \mathrm{P}<0.05)$ and IL-6 $(27.5 \pm 0.0 \mathrm{pg} / \mathrm{ml}$ vs. $588.2 \pm 61.8 \mathrm{pg} / \mathrm{ml} ; \mathrm{P}<0.05)$ levels in the BALF. IL-1 $\beta$ levels $(105.3 \pm 22.6 \mathrm{pg} / \mathrm{ml}, \mathrm{P}<0.05)$ and IL-6 levels $(281.7 \pm 56.3 \mathrm{pg} / \mathrm{ml}, \mathrm{P}<0.05)$ were significantly lower in the LPS/ MSC group when compared to that of the LPS group (Figure $4 \mathrm{~B}$ and $\mathrm{C}$ ). However, the level of MIP-2 was significantly higher in the LPS group $(252.8 \pm 31.1 \mathrm{pg} / \mathrm{ml})$ and the LPS/MSC
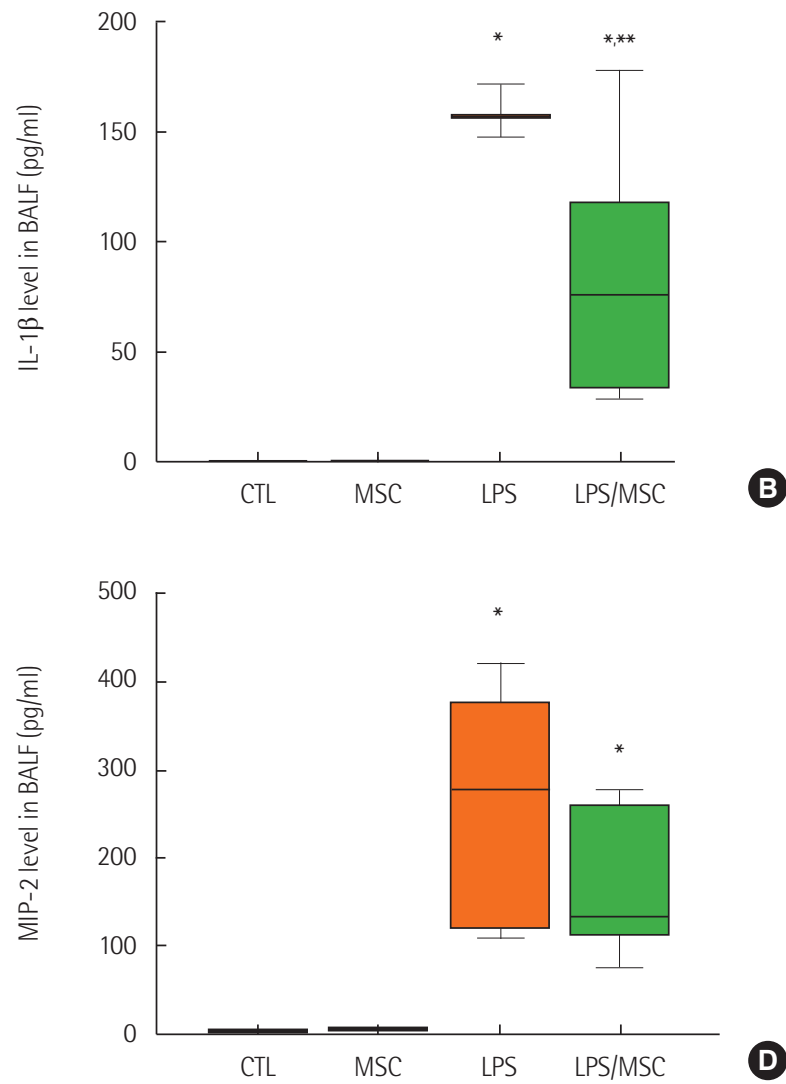

Figure 4. Mesenchymal stem cells attenuate lipopolysaccharide-induced acute lung injury by anti-inflammatory effects. (A) Tumor necrosis factor (TNF)- $\alpha_{1}$ (B) interleukin (IL)-1 $\beta$, (C) IL-6, and (D) macrophage inflammatory protein (MIP)-2 in bronchoalveolar lavage fluid (BALF). CTL: control group; MSC: mesenchymal stem cell injected group; LPS: lipopolysaccharide-induced acute lung injury group; LPS/MSC: MSC injection following LPS induced acute lung injury group. ${ }^{*} \mathrm{P}<0.05$, compared to the CTL group; ${ }^{* *} \mathrm{P}<0.05$, compared to the LPS group. 

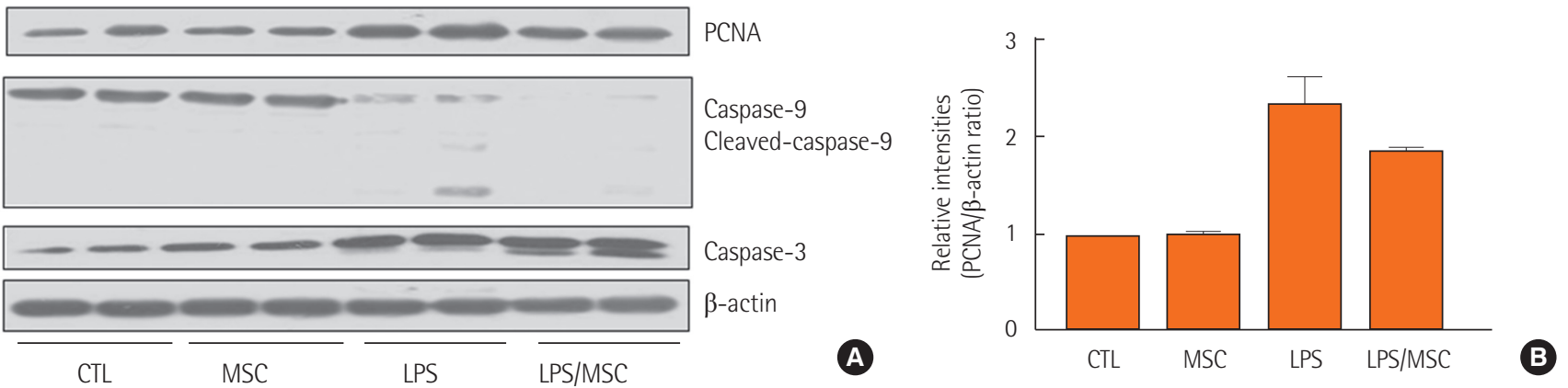

Figure 5. The effect of mesenchymal stem cells on proliferation and cell death. (A) Western blot of proliferation cell nuclear antigen (PCNA), caspase- 9 and cleaved-caspase-9, caspase- 3 , and $\beta$-actin. (B) Relative protein level (PCNA/ $\beta$-actin ratio). CTL: control group; MSC: mesenchymal stem cell injected group; LPS: lipopolysaccharide-induced acute lung injury group; LPS/MSC: MSC injection following LPS induced acute lung injury group.

group (166.2 $\pm 26.2 \mathrm{pg} / \mathrm{ml})$ when compared to that of the control group $(0.0 \pm 0.0 \mathrm{pg} / \mathrm{ml}, \mathrm{P}<0.05)$ (Figure 4D).

\section{Cell Proliferation and Apoptosis}

Western blot analysis showed that the expression of PCNA and caspase-3 increased in the LPS group. MSC treatment attenuated the expression of PCNA, but showed no significant changes in caspase-3 and caspase-9 (Figure 5).

\section{Growth Factor}

HGF levels in the BALF were higher in the LPS group compared to those in the CTL group $(378.9 \pm 108.1 \mathrm{pg} / \mathrm{ml}$ vs. $54.7 \pm 14.3$ $\mathrm{pg} / \mathrm{ml}, \mathrm{P}<0.05)$. However, HGF levels did not significantly change in the LPS/MSC group $(255.4 \pm 86.5 \mathrm{pg} / \mathrm{ml})$.

\section{DISCUSSION}

In this study, we evaluated the early effect of allogenic MSCs in an LPS-induced ALI animal model by analyzing various inflammatory mediators, proliferation markers, markers of apoptosis, and histological changes. We showed that the injection of MSCs decreased the infiltration of neutrophils and early inflammatory cytokines including TNF- $\alpha$, IL- $1 \beta$, and IL- 6 , but showed no effect on apoptosis and the regulation of HGF. The therapeutic effect of MSCs is considered an anti-inflammatory effect of MSCs in early stage of ALI.

The pathophysiology of ALI is a physiological inflammatory response that causes extensive damage to the alveolar-capillary membrane through the actions of alveolar macrophages, neutrophils, platelets, TNF- $\alpha$, proteases, arachidonic acid metabolites, and oxygen radicals [28]. Sepsis-induced ALI is caused by the interaction of inflammatory cytokines, such as IL-1 $\beta$, IL-6, and TNF- $\alpha$, derived from neutrophils, alveolar macro- phages, and vascular endothelial cells activated by endotoxin [29]. When LPS is injected into mice, inflammation can be noticed after 4-5 hours [30]. Therefore, MSCs were injected 4 hours after LPS injection in our model. LPS induces the infiltration of neutrophils from the blood into the alveoli, which simultaneously damages the first and second alveoli and vascular endothelial cells, thus destroying the epithelial and vascular barriers, causing alveolar flooding [23]. In LPS-induced ALI, cytokines are signaling molecules that play an important role in starting, amplifying, and sustaining an inflammatory reaction. Proinflammatory cytokines, such as TNF- $\alpha$ and IL$1 \beta$, appear in the early stage of lung injury and are known to aggravate the inflammatory reaction by inducing the secretion of chemokines and immunomodulators. High concentrations of those cytokines are observed in the BALF of a patient with ARDS or at high risk for ARDS [31,32]. IL-6 is produced by an activated macrophage; it stimulates acute inflammation. IL- 6 concentration is highly elevated in the BALF of patients who are at high risk of an ALI. The high concentration is maintained until the ALI is confirmed. After injecting IL-1 $\beta$ in vivo and in vitro, a cytokine-induced neutrophil chemotactic factor is produced and detached. This induces the inflow of active neutrophils into the alveoli [33]. Therefore, in this study, TNF- $\alpha$, IL-1 $\beta$, and IL- 6 levels were measured to assess the effect of MSC injection on the relevance of cytokines in LPS-induced ALI.

MIP is an inflammatory mediator, which is produced from various cells, such as macrophages, polymorphonuclear cells, $\mathrm{T}$ cells, eosinophils, basophils, and platelets, that induces local inflammatory reaction as it quickly attracts neutrophils [34]. This study showed that the concentration of MIP-2 in BALF did not decrease with the MSC injection.

Both proliferation and cell death were activated in LPS-in- 
duced ALI. MSCs partially suppressed proliferation, but had no effect on cell death. The conquest to cure incurable diseases using stem cells has arose as an important issue in regeneration medicine and has been applied in almost every field of medicine, including cardiology, neurology, hematology, immunology, genetics, pulmonology, hepatology, and in bone, cartilage, and skin diseases. Even though the positive effects of MSCs are reported for various diseases, the mechanism of treatment has not been proved. In addition, the therapeutic effect differs depending on the stem cell type and number and the injection route, time, and number.

In our study, we focused on the early therapeutic effect of allogenic bone marrow-derived MSCs in an LPS-induced ALI animal model. Though MSCs attenuated the LPS-induced ALI through decreasing neutrophils and inflammatory factors, it had little effects on cell death and growth hormone in the early stage. Our findings suggest that allogenic MSCs are still a promising clinical therapeutic modality, but the mechanism and safety of MSCs have not been established.

\section{CONFLICT OF INTEREST}

No potential conflict of interest relevant to this article was reported.

\section{ACKNOWLEDGMENTS}

This study was supported by a grant 10-375 from the Asan Institute for Life Science, Asan Medical Center, Seoul, Korea.

\section{ORCID}

Jin Won Huh http://orcid.org/0000-0002-3449-0461

Won Young Kim http://orcid.org/0000-0002-6904-5966

Chae-Man Lim http://orcid.org/0000-0001-5400-6588

Younsuck Koh http://orcid.org/0000-0001-5066-2027

Sang-Bum Hong http://orcid.org/0000-0003-2737-7695

\section{SUPPLEMENTARY MATERIAL}

The online-only Supplement data are available with this article online: https://doi.org/acc.2018.00619.

\section{REFERENCES}

1. Rubenfeld GD, Caldwell E, Peabody E, Weaver J, Martin DP, Neff $\mathrm{M}$, et al. Incidence and outcomes of acute lung injury. $\mathrm{N}$
Engl J Med 2005;353:1685-93.

2. Bellani G, Laffey JG, Pham T, Fan E, Brochard L, Esteban A, et al. Epidemiology, patterns of care, and mortality for patients with acute respiratory distress syndrome in intensive care units in 50 countries. JAMA 2016;315:788-800.

3. Zambon M, Vincent JL. Mortality rates for patients with acute lung injury/ARDS have decreased over time. Chest 2008;133: 1120-7.

4. Amato MB, Barbas CS, Medeiros DM, Magaldi RB, Schettino GP, Lorenzi-Filho G, et al. Effect of a protective-ventilation strategy on mortality in the acute respiratory distress syndrome. N Engl J Med 1998;338:347-54.

5. Guérin C, Reignier J, Richard JC, Beuret P, Gacouin A, Boulain $\mathrm{T}$, et al. Prone positioning in severe acute respiratory distress syndrome. N Engl J Med 2013;368:2159-68.

6. Peek GJ, Mugford M, Tiruvoipati R, Wilson A, Allen E, Thalanany $\mathrm{MM}$, et al. Efficacy and economic assessment of conventional ventilatory support versus extracorporeal membrane oxygenation for severe adult respiratory failure (CESAR): a multicentre randomised controlled trial. Lancet 2009;374:135163.

7. Hudson LD, Milberg JA, Anardi D, Maunder RJ. Clinical risks for development of the acute respiratory distress syndrome. Am J Respir Crit Care Med 1995;151:293-301.

8. Doyle RL, Szaflarski N, Modin GW, Wiener-Kronish JP, Matthay MA. Identification of patients with acute lung injury. Predictors of mortality. Am J Respir Crit Care Med 1995;152:181824.

9. Matthay MA, Zimmerman GA. Acute lung injury and the acute respiratory distress syndrome: four decades of inquiry into pathogenesis and rational management. Am J Respir Cell Mol Biol 2005;33:319-27.

10. Chollet-Martin S. Polymorphonuclear neutrophil activation during the acute respiratory distress syndrome. Intensive Care Med 2000;26:1575-7.

11. Abraham E. Neutrophils and acute lung injury. Crit Care Med 2003;31(4 Suppl):S195-9.

12. Stephens KE, Ishizaka A, Wu ZH, Larrick JW, Raffin TA. Granulocyte depletion prevents tumor necrosis factor-mediated acute lung injury in guinea pigs. Am Rev Respir Dis 1988;138: $1300-7$.

13. Perkins GD, Nathani N, McAuley DF, Gao F, Thickett DR. In vitro and in vivo effects of salbutamol on neutrophil function in acute lung injury. Thorax 2007;62:36-42.

14. Pittenger MF, Mackay AM, Beck SC, Jaiswal RK, Douglas R, Mosca JD, et al. Multilineage potential of adult human mesenchymal stem cells. Science 1999;284:143-7. 
15. Li TS, Hayashi M, Ito H, Furutani A, Murata T, Matsuzaki M, et al. Regeneration of infarcted myocardium by intramyocardial implantation of ex vivo transforming growth factor-betapreprogrammed bone marrow stem cells. Circulation 2005; 111:2438-45.

16. Miyahara Y, Nagaya N, Kataoka M, Yanagawa B, Tanaka K, Hao $\mathrm{H}$, et al. Monolayered mesenchymal stem cells repair scarred myocardium after myocardial infarction. Nat Med 2006;12:459-65.

17. Lee RH, Pulin AA, Seo MJ, Kota DJ, Ylostalo J, Larson BL, et al. Intravenous hMSCs improve myocardial infarction in mice because cells embolized in lung are activated to secrete the anti-inflammatory protein TSG-6. Cell Stem Cell 2009;5:5463.

18. Parekkadan B, van Poll D, Suganuma K, Carter EA, Berthiaume F, Tilles AW, et al. Mesenchymal stem cell-derived molecules reverse fulminant hepatic failure. PLoS One 2007;2:e941.

19. Mei SH, Haitsma JJ, Dos Santos CC, Deng Y, Lai PF, Slutsky AS, et al. Mesenchymal stem cells reduce inflammation while enhancing bacterial clearance and improving survival in sepsis. Am J Respir Crit Care Med 2010;182:1047-57.

20. Ortiz LA, Gambelli F, McBride C, Gaupp D, Baddoo M, Kaminski N, et al. Mesenchymal stem cell engraftment in lung is enhanced in response to bleomycin exposure and ameliorates its fibrotic effects. Proc Natl Acad Sci U S A 2003;100:8407-11.

21. Rojas M, Woods CR, Mora AL, Xu J, Brigham KL. Endotoxininduced lung injury in mice: structural, functional, and biochemical responses. Am J Physiol Lung Cell Mol Physiol 2005; 288:L333-41.

22. Gupta N, Su X, Popov B, Lee JW, Serikov V, Matthay MA. Intrapulmonary delivery of bone marrow-derived mesenchymal stem cells improves survival and attenuates endotoxininduced acute lung injury in mice. J Immunol 2007;179:185563.

23. van Helden HP, Kuijpers WC, Steenvoorden D, Go C, Bruijnzeel PL, van Eijk M, et al. Intratracheal aerosolization of endotoxin (LPS) in the rat: a comprehensive animal model to study adult (acute) respiratory distress syndrome. Exp Lung Res 1997;23:297-316.

24. Kim ES, Chang YS, Choi SJ, Kim JK, Yoo HS, Ahn SY, et al. Intratracheal transplantation of human umbilical cord blood- derived mesenchymal stem cells attenuates Escherichia coliinduced acute lung injury in mice. Respir Res 2011;12:108.

25. Dominici M, Le Blanc K, Mueller I, Slaper-Cortenbach I, Marini F, Krause D, et al. Minimal criteria for defining multipotent mesenchymal stromal cells. The International Society for Cellular Therapy position statement. Cytotherapy 2006;8:315-7.

26. Everhart MB, Han W, Sherrill TP, Arutiunov M, Polosukhin VV, Burke JR, et al. Duration and intensity of NF-kappaB activity determine the severity of endotoxin-induced acute lung injury. J Immunol 2006;176:4995-5005.

27. Hong SB, Koh Y, Lee IC, Kim MJ, Kim WS, Kim DS, et al. Induced hypothermia as a new approach to lung rest for the acutely injured lung. Crit Care Med 2005;33:2049-55.

28. Ware LB, Matthay MA. The acute respiratory distress syndrome. N Engl J Med 2000;342:1334-49.

29. Pugin J, Ricou B, Steinberg KP, Suter PM, Martin TR. Proinflammatory activity in bronchoalveolar lavage fluids from patients with ARDS, a prominent role for interleukin-1. Am J Respir Crit Care Med 1996;153:1850-6.

30. Koh Y, Lee YM, Lim CM, Lee SS, Shim TS, Lee SD, et al. Effects of heat pretreatment on histopathology, cytokine production, and surfactant in endotoxin-induced acute lung injury. Inflammation 2001;25:187-96.

31. Schütte H, Lohmeyer J, Rosseau S, Ziegler S, Siebert C, Kielisch $\mathrm{H}$, et al. Bronchoalveolar and systemic cytokine profiles in patients with ARDS, severe pneumonia and cardiogenic pulmonary oedema. Eur Respir J 1996;9:1858-67.

32. Suter PM, Suter S, Girardin E, Roux-Lombard P, Grau GE, Dayer JM. High bronchoalveolar levels of tumor necrosis factor and its inhibitors, interleukin-1, interferon, and elastase, in patients with adult respiratory distress syndrome after trauma, shock, or sepsis. Am Rev Respir Dis 1992;145:1016-22.

33. Koh Y, Hybertson BM, Jepson EK, Cho OJ, Repine JE. Cytokine-induced neutrophil chemoattractant is necessary for interleukin-1-induced lung leak in rats. J Appl Physiol 1995;79: 472-8.

34. Kawamura H, Kawamura T, Kanda Y, Kobayashi T, Abo T. Extracellular ATP-stimulated macrophages produce macrophage inflammatory protein-2 which is important for neutrophil migration. Immunology 2012;136:448-58. 
CD34

Negative

$$
\text { 元 }
$$

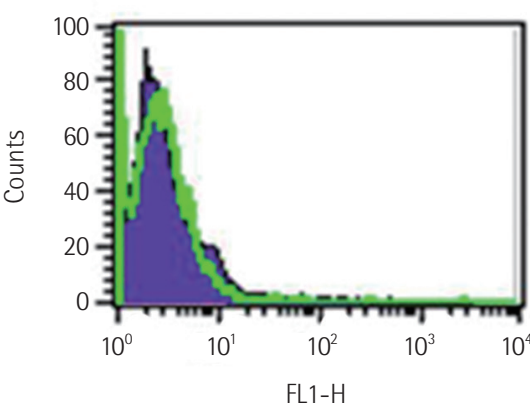

Positive

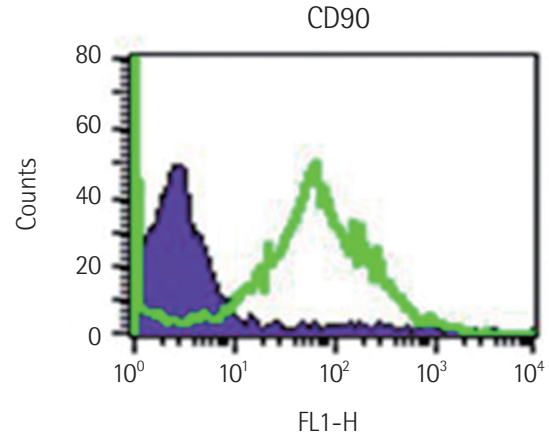

CD45
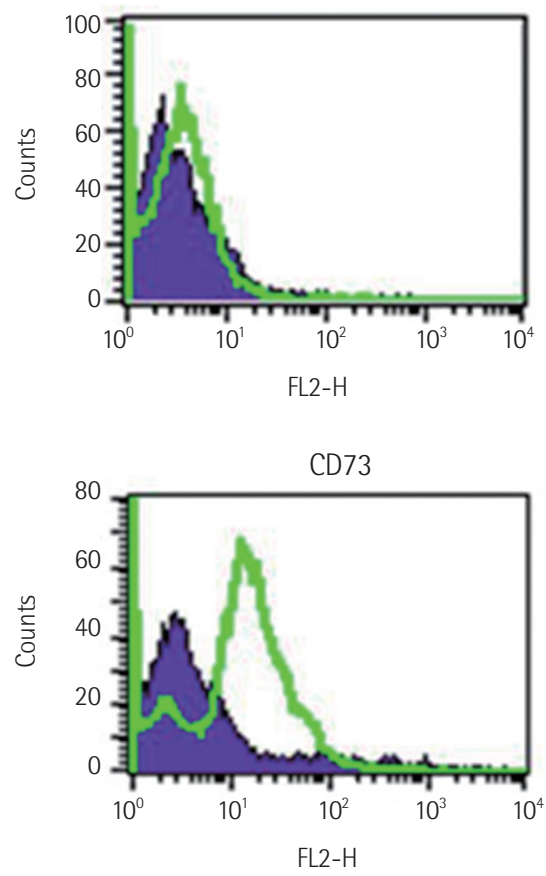

Supplementary Figure 1. Characteristics of mesenchymal stem cells using monoclonal antibodies. 